\title{
Nie tylko Teleranek \\ (Nie)obecność filmów zagranicznych w Telewizji Polskiej w stanie wojennym
}

\section{MICHAŁ PIEPIÓRKA}

13 grudnia 1981 r. nie było Teleranka. To sformułowanie stało się emblematyczne dla pamięci o stanie wojennym, dzięki czemu została ona ściśle powiązana z telewizją. W zbiorowej pamięci zachowały się jeszcze niesławne konferencje Jerzego Urbana czy umundurowani prezenterzy Dziennika Telewizyjnego. Również w piśmiennictwie dotyczącym telewizji tamtego okresu najchętniej opisuje się propagandowe wykorzystywanie publicystyki do oczerniania działaczy „Solidarności”, a także tzw. weryfikację, w wyniku której wielu dziennikarzy zostało zwolnionych lub odsuniętych od pracy. Znacznie rzadziej wspomina się natomiast o tym, co emitowano między wydaniami Dziennika Telewizyjnego, transmisjami z mistrzostw świata w piłce nożnej España 82 i z pielgrzymki Jana Pawła II do Polski, czyli o filmach ${ }^{1}$, które przecież w nie mniejszym stopniu jak programy informacyjno-publicystyczne stanowiły oręż władzy w walce o umysły telewidzów.

W tekście tym będzie mnie interesować polityka kształtowania ramówki przez władze telewizji w czasie trwania stanu wojennego - od 13 grudnia 1981 r. do 22 lipca 1983 r., czyli również po formalnym zawieszeniu stanu wyjątkowego, które miało miejsce 31 grudnia $1982 \mathrm{r}$. Biorę przy tym pod uwagę, że nie był to okres monolityczny. Inaczej kształtował się program w pierwszych dniach po wystąpieniu gen. Wojciecha Jaruzelskiego, a inaczej w połowie 1982 r. czy w 1983 r. Jednym z celów tego tekstu jest ustalenie przyczyn takiego stanu rzeczy. Szczególny nacisk kładę na miejsce w programie filmów zagranicznych, które dzielę zgodnie z ówczesną polityką zagraniczną polskiego rządu - na te z krajów socjalistycznych i kapitalistycznych. Analizowane wypowiedzi decydentów jasno wskazują, że właśnie takie bipolarne myślenie warunkowało ówczesne realia polityczne i wpływało zarówno na decyzje zakupowe, jak i emisyjne. Jest to także widoczne, gdy porówna się ramówki telewizyjne sprzed stanu wojennego i te układane po 13 grudnia 1981 r. Zachodząca w programie zmiana dotyczyła w głównej mierze korekty proporcji między filmami z krajów socjalistycznych i zachodnich.

W artykule w znacznym stopniu skupiam się na badaniach ilościowych i wykorzystuję dane zebrane w procesie analizy ramówek telewizyjnych. Posługiwałem się dwoma źródłami: programami telewizyjnymi publikowanymi w „Trybunie Ludu" (od 16 grudnia 1981 r. $^{2}$ do 23 maja 1982 r., czyli w okresie, kiedy nie wydawano innych czasopism z programem telewizyjnym) i w „Antenie” (od 24 maja 1982 r. do 22 lipca 1983 r.). W ten sposób powstała baza gromadząca tytuły wszystkich filmów pełnometrażowych (534 zagranicznych i 192 polskich) i seriali (117 zagranicznych i 58 polskich) emitowanych w stanie wojennym. Drugim etapem pracy była identyfikacja filmów. W programie przy tytule często widniało nazwisko 
reżysera, kraj produkcji i kategoria wskazująca na gatunek, nierzadko również obsada. To pozwoliło mi zidentyfikować filmy ${ }^{3} \mathrm{w}$ portalu IMDb i uzupełnić bazę o brakujące informacje, takie jak ich tytuły oryginalne czy daty powstania. Taki sposób gromadzenia materiałów wiąże się, oczywiście, z pewnymi zagrożeniami. Najważniejszym z nich były nieoczekiwane zmiany w ramówce, czyli niezgodność tego, co planowane z tym, co faktycznie wyemitowane. Można sądzić, że w analizowanym okresie zdarzało się to często ${ }^{4}$. Innym problemem były na przykład błędy w programie, takie jak niewłaściwe przypisanie kraju produkcji czy nawet nazwiska reżysera.

Częścią badań była również analiza określeń gatunkowych emitowanych filmów. Wiedzę o nich czerpałem z dwóch źródeł: z programu telewizyjnego oraz w przypadku filmów zagranicznych - z serwisu IMDb, a w przypadku polskich z serwisu filmpolski.pl. W ten sposób każdy film mógł zyskać kilka etykiet gatunkowych. Rekordzistą w tym zakresie był Niezwyciężony Bill (The Plainsman, 1936) Cecila B. DeMille’a, przy którym pojawiło się aż pięć określeń: dramat, film biograficzny, film historyczny, romans i western. Ostateczny zbiór widoczny na wykresie jest zbiorem wszystkich określeń, jakie pojawiły się przy zidentyfikowanych filmach emitowanych w Telewizji Polskiej w okresie stanu wojennego. To też wyjaśnia, dlaczego na wykresach liczba określeń gatunkowych przekracza sumę emitowanych filmów.

\section{Odwrócenie proporcji, czyli powolna rewolucja}

O tym, jak wielkie zmiany zaszły w stanie wojennym w zakresie emisji filmów zagranicznych, można się przekonać, analizując choćby program telewizyjny w pierwszych dniach po wystąpieniu Wojciecha Jaruzelskiego. Powszechnie pamięta się, że 13 grudnia nie było Teleranka, ale już znacznie mniej osób wie o tym, że w związku z tym nie wyemitowano kanadyjskiego serialu Matt i Jenny na dzikim szlaku (Matt and Jenny, 1979), a tego samego dnia jeszcze takich seriali, jak japońskie Przygody Sindbada (Arabian naitsu: Shinbaddo no bôken, 1975-), angielski Klan Cameronów (The Camerons, 1979-) i francuskie: Biały delfin (Oum le dauphin blanc, 1971-), Józefina i Napoleon (Joséphine ou la comédie des ambitions, 1979-), Samochody i ludzie oraz Koń mój przyjaciel. W paśmie wieczornym nie pokazano zaś amerykańskiej produkcji: Sierżant Anderson (Police Woman, 1974-1978). W pierwszych dniach stanu wojennego planowano jeszcze emisje seriali: Wszystkie zwierzęta mate i duże (All Creatures Great and Small, Wielka Brytania, 1978-1990), Spadła z obłoków (Spadla z oblakov, Czechosłowacja, 1978) oraz Larysa (ZSRR) i Wybuch wulkanów (ZSRR). Dodatkowo, jeszcze przed ogłoszeniem stanu wojennego, na okres od 13 do 19 grudnia zapowiedziano emisję czterech filmów: francuskiego Dzikiego dziecka (L'enfant sauvage, 1970) François Truffauta, węgiersko-fińskiego Matżeństwa wolnego od cła (Vámmentes házasság, 1980) Jánosa Zsombolyaia, amerykańskiego Swobodnego jeźdźca (Easy Rider, 1969) Dennisa Hoppera i hiszpańskiej Obietnicy (La promesa, 1974) Josefiny Moliny.

Nietrudno zauważyć, jakie filmy dominowały w planowanej na pierwsze dni stanu wojennego, a niewyemitowanej ramówce. Najwięcej z nich pochodziło z kręgu krajów kapitalistycznych - z Francji, Anglii, Kanady, Stanów Zjednoczo- 
nych czy Japonii. Filmy z zaprzyjaźnionego bloku wschodniego stanowiły margines. Na szesnaście pozycji zagranicznych aż dwanaście wyprodukowano w krajach zachodnich, jedna była koprodukcją kraju zachodniego z socjalistycznym i zaledwie trzy zostały nakręcone w państwach socjalistycznych. To nie był przypadek ani wyjątek. Przed wprowadzeniem stanu wojennego - zarówno w roku 1981, a tym bardziej w 1980 i pod koniec lat 70. - w telewizji obok produkcji polskich dominowały filmy i seriale sprowadzane właśnie z Zachodu. Szczególnie bogaty był program z pierwszego półrocza 1980 r. Zapewne miał on dowodzić „otwarcia na świat" przez władze PRL, a zarazem odwrócić uwagę widzów od rzeczywistości pogłębiającego się kryzysu ekonomicznego, a zarazem ograniczać udział Polaków w „lokalnych niepokojach”. W połowie 1980 r. ten model programowy powoli się wyczerpywał, wykorzystano zapasy produkcji najbardziej pożądanych i zaczęło brakować dewiz na zakup kolejnych atrakcyjnych filmów z Zachodu. Tytuły z krajów socjalistycznych powoli zaczęły wypierać te z kręgu zachodniego. Był to jednak długi proces, który w momencie wprowadzenia stanu wojennego gwałtownie przyśpieszył ${ }^{5}$. Jak relacjonuje Kozieł, zwiększenie liczby pokazywanych w telewizji produkcji z krajów socjalistycznych - zarówno filmów, jak i programów publicystycznych, reportaży i programów muzycznych - miało również cel psychologiczny. Już w pierwszym półroczu 1981 r. władza zacieśniła współpracę z Interwizją ${ }^{6}$, by dostarczając materiały z ZSRR i innych bratnich krajów, wskazywać na kontrast między codziennym spokojem w tamtych państwach i ,niepokojami" w Polsce ${ }^{7}$.

By się przekonać, jaka zmiana zaszła w stanie wojennym odnośnie do polityki emitowania filmów z krajów kapitalistycznych i socjalistycznych, można spojrzeć na dwa wykresy: pierwszy przedstawia strukturę programu telewizyjnego ${ }^{8}$ na zaledwie dwa tygodnie przed wprowadzeniem stanu wojennego, drugi pokazuje proporcje w ramówce filmów z Zachodu, krajów socjalistycznych i Polski w okresie całego stanu wojennego (zob. Wykres 1 i Wykres 2). W listopadzie 1981 r. aż 50 proc. emitowanych filmów i seriali było produkcji zachodniej, natomiast tytuły z bloku państw socjalistycznych ${ }^{9}$ stanowiły zaledwie 23 proc. programu, a niewiele więcej, bo 27 proc., pochodziło z Polski. W okresie stanu wojennego sytuacja całkowicie się zmianiła i proporcje się odwróciły. 48 proc. filmów i seriali emitowanych w okresie od 13 grudnia 1981 r. do 22 lipca 1983 r. było produkcji socjalistycznej, a zachodnich było zaledwie 20 proc. Co ciekawe, udział tytułów polskich niemal się nie zmienił - pozostał na wysokości 28 proc. Nie oznacza to oczywiście, że nie zmienił się profil pokazywanych filmów rodzimej produkcji. Włodarze telewizji mieli ulubionych reżyserów, których twórczość wyrażała treści zbieżne z tym, co starała się propagować partia za pomocą podległych mediów.

Już analiza programu pierwszych dni stanu wojennego pokazuje, o jakich twórcach i treściach mowa. 13 grudnia - w paśmie wieczornym, zaraz po wyjątkowo długim wydaniu Dziennika Telewizyjnego, w którym kilkukrotnie wyemitowano wystąpienie Wojciecha Jaruzelskiego - pokazano tylko jeden film. Była to Jarzębina czerwona (1969) Ewy i Czesława Petelskich. Opowiadając o bitwie o Kołobrzeg, obraz stawiał w dobrym świetle ludzi odpowiedzialnych za wprowadzenie stanu wojennego, w tym samego gen. Wojciecha Jaruzelskiego, który miał się wsławić dzielnością właśnie w tej bitwie. Wybór filmu w żadnym razie nie był więc przypadkowy. Potwierdził to Tadeusz Pikulski w Prywatnej historii telewizji pub- 
licznej, pisząc, że już od połowy 1981 r. przygotowywano się na stan wyjątkowy i debatowano między innymi nad charakterem ramówki w pierwszych dniach po jego wprowadzeniu: $W K C$ (...) podczas meczacych narad ustalano repertuar filmowy. Ostatecznie stanęło na podbijaniu bębenka ,patriotyzmu” ${ }^{10}$.

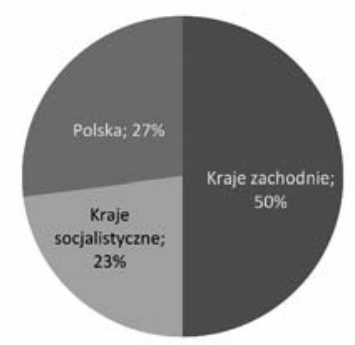

Wykres 1. Procentowa struktura programu w listopadzie 1981 r. z podziałem na kraje produkcji emitowanych filmów i seriali. $\mathrm{n}=100 \%$

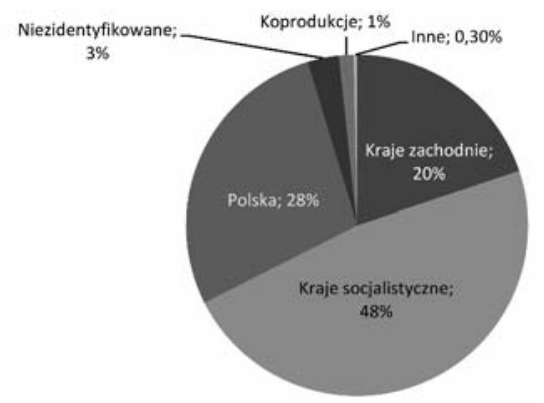

Wykres 2. Procentowa struktura programu w stanie wojennym $\mathrm{z}$ podziałem na kraje produkcji emitowanych filmów i seriali. $\mathrm{n}=100 \%$

Przez cały okres stanu wojennego filmy historyczne o odpowiednim wydźwięku ideologicznym miały szczególne miejsce w programie. Już w pierwszych dniach na antenie pojawiły się takie filmy, jak Pasja (1977) Stanisława Różewicza i Godziny nadziei (1955) Jana Rybkowskiego, które razem z umundurowanymi prezenterami, piosenkami wojskowymi i programami o wojskowości miały współtworzyć, jak pisał Pikulski ${ }^{11}$, patriotyczny sos, w którym była skąpana cała ramówka początku stanu wojennego. Wymienione filmy wojenne były więc częścią przemyślanej całości. Tak ułożony program miał również na celu budowanie atmosfery powagi. Rządzącym zależało, by wykreować poczucie doniosłości chwili, a nawet wywołać atmosferę psychozy ${ }^{12}$ - dlatego też w pierwszych dniach stanu wojennego wyeliminowano z ramówki wszelkie programy rozrywkowe, a na antenie panował wyjątkowo podniosły nastrój. Oprócz wspomnianych trzech filmów wyemitowano jeszcze tylko Con amore (1976) Jana Batorego.

Polskie produkcje były obecne na szklanych ekranach od samego początku omawianego okresu, inaczej było w przypadku filmów zagranicznych. Z wymienionych wcześniej tytułów programowanych na czas pierwszych dni stanu wojennego planowo wyemitowano jedynie odcinek czechosłowackiego serialu Spadła z obłoków. Natomiast pierwszym zagranicznym filmem pokazywanym w stanie wojennym była amerykańska Rebeka (Rebecca, 1940) Alfreda Hitchcocka, będąca pewnego rodzaju prezentem na święta Bożego Narodzenia (wyemitowano ją w Wigilię). Wcześniej, 19 grudnia, pokazano jeden odcinek angielskiego serialu Władcy powietrza, a 20 grudnia - serialu animowanego Przygody Sindbada. Warto jednak zauważyć, że wszystkie tytuły, które zapowiadano w programie opublikowanym 
przed 13 grudnia - zarówno seriale, jak i filmy - znalazły swój czas antenowy w późniejszym terminie ${ }^{13}$. Dotyczy to również Swobodnego jeźdźca, który stanowi wyjątkowy przypadek, o czym piszę dalej.

Jak wspomniałem, w stanie wojennym dominacja filmów i seriali z krajów socjalistycznych była olbrzymia, a te z Polski stanowiły zaledwie nieco ponad jedną czwartą całości. Jednak jeśli na moment porzucić dualistyczny podział (socjalistyczne - kapitalistyczne), a przyjrzeć się krajom produkcji, to okaże się, że najliczniejsze były te rodzime (zob. Wykres 3). Produkcji polskich wyemitowano w tamtym okresie aż 252, a zajmujący pod tym względem drugie miejsce Związek Radziecki był odpowiedzialny za ,zaledwie” 159 pozycji. Nie oznacza to jednak, że zupełnie zrezygnowano z importowania filmów i seriali z Zachodu, choć z różnych względów, o których piszę dalej, telewizja nie mogła sobie na to pozwolić. Spośród krajów kapitalistycznych liderem pod względem eksportu do Polski były Stany Zjednoczone (53 tytuły) oraz Francja (47), ale w tym okresie telewidzowie mogli obejrzeć również produkcje z Wielkiej Brytanii, Hiszpanii, Włoch, RFN, Kanady, Szwecji, Japonii, Finlandii, Norwegii, Danii, Holandii, Irlandii, Australii, Szwajcarii i Austrii. W programie znalazły się również filmy z czterech krajów, które trudno przyporządkować do którejś z tych dwóch grup ${ }^{14}$ - mam na myśli Maroko (Krwawe gody /Noces de sang/, reż. Souheil Ben-Barka, 1980), Meksyk (Mariachi /Mariachi - fiesta de sangrel, reż. Rafael Portillo, 1977), Kamerun (Cena wolności /Le prix de la libertél, reż. Jean-Pierre Dikongué Pipa, 1978) i Nigerię (Toula /Toula ou le génie des eaux/, reż. Moustapha Alassane, Anna Soehring, 1974) ${ }^{15}$.

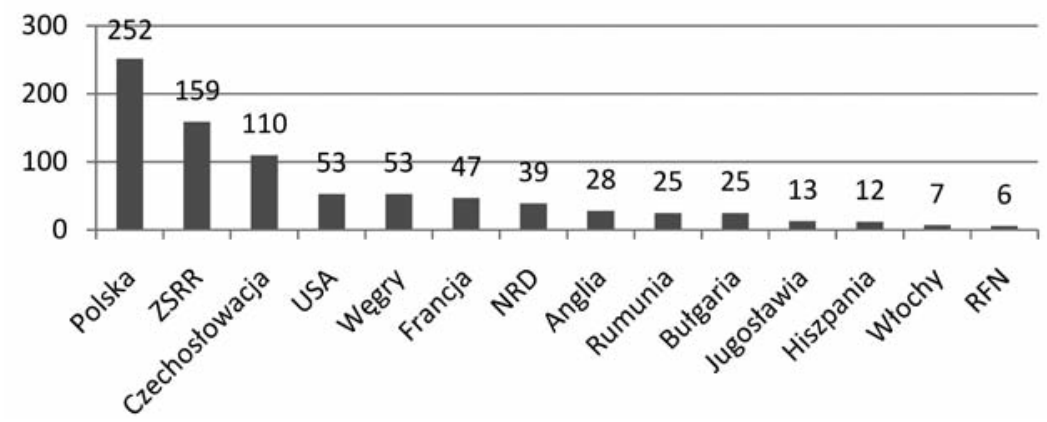

Wykres 3. Liczba filmów i seriali emitowanych w telewizji w stanie wojennym z podziałem na kraje produkcji (uwzględniono kraje, które dostarczyły powyżej 5 tytułów). $\mathrm{n}=829$ filmów i seriali

Widząc tak wielką zmianę w doborze filmów do ramówki, można byłoby sądzić, że przeskok z faworyzowania filmów z krajów kapitalistycznych do stawiania na te socjalistyczne był natychmiastowy, a 13 grudnia na dobre odmieniono program. Tak jednak nie było. Wspomniałem już, że w okresie od 13 do 24 grudnia pokazano dwie produkcje brytyjskie, jedną japońską i jedną czechosłowacką, czyli w pierwszych dniach stanu wojennego nadal dominowały tytuły z krajów zachodnich. Ta sytuacja nie zmieniła się przez całe dwa pierwsze miesiące stanu wojennego. Zarówno $\mathrm{w}$ grudniu ${ }^{16}$, jak i w styczniu filmy zachodnie górowały liczbowo nad pozycjami z bloku wschodniego. Jak pokazuje Wykres 4., ustępowały one jednak tytułom polskim. Zmiana nastąpiła dopiero w lutym 1982 r. Był to pierwszy 
miesiąc w okresie stanu wojennego, kiedy w programie telewizyjnym znalazło się więcej filmów produkcji socjalistycznej niż kapitalistycznej czy nawet polskiej. Ta sytuacja nie zmieni się już do końca stanu wojennego ${ }^{17}$. Jednak w okresie od lutego do maja 1982 r. filmy z krajów socjalistycznych nie dominowały jeszcze w ramówce w takim stopniu, jak w kolejnych miesiącach (choć i tak przewaga filmów i seriali z krajów socjalistycznych była już wtedy znacząca - stanowiły w tym okresie aż 43 proc. wszystkich pokazywanych w tym czasie tytułów, produkcje zachodnie stanowiły 26 proc., a polskie 31 proc.). Prawdziwy przełom nastąpił dopiero w czerwcu i lipcu, czyli pół roku po wprowadzeniu stanu wojennego. To pokazuje, jak różnorodny pod względem polityki emisyjnej był omawiany okres oraz jak bardzo filmy z tych krajów dominowały w kolejnych miesiącach. Dla przykładu, w sierpniu 1982 r. procent filmów z bloku wschodniego wynosił aż 69, zachodnich -18 , a polskich -13 . Radykalna zmiana w programie w końcu nastąpiła, ale była wprowadzana powoli.

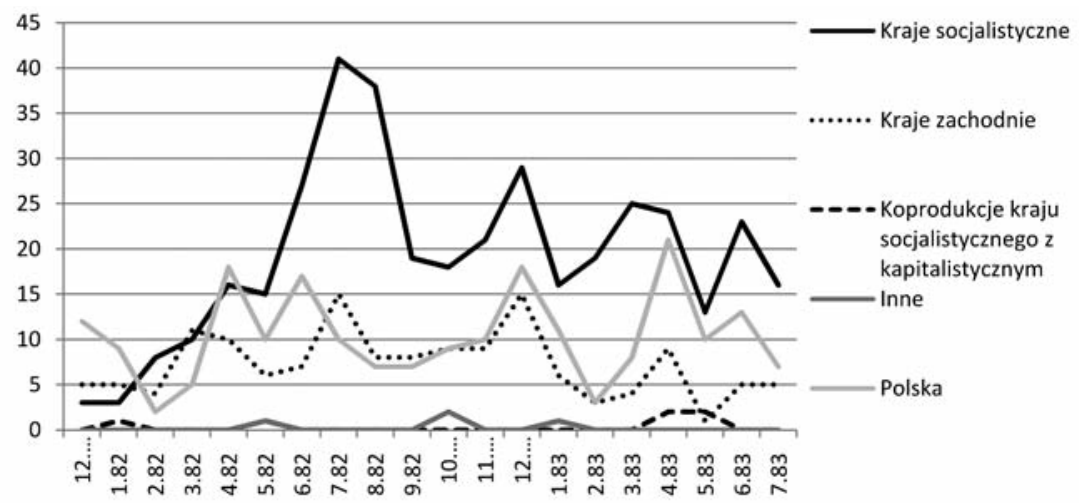

Wykres 4. Liczba emisji filmów pokazywanych w telewizji w stanie wojennym z podziałem na kraje produkcji w strukturze miesięcznej. $n=746$ filmów i seriali

\section{Kryzys, propaganda i bojkot, czyli skąd się wzięła rewolucja programowa}

Co takiego się więc wydarzyło, że w pewnym momencie stanu wojennego tak bardzo odmieniono ramówkę na korzyść filmów i seriali z krajów socjalistycznych? Na to pytanie można odpowiedzieć na trzy sposoby: po pierwsze, odpowiedzialny był tu pogłębiający się kryzys gospodarczy, który sprawiał, że włodarzom brakowało funduszy, szczególnie w postaci dewiz, na drogie produkcje z Zachodu. W prasie pisano wówczas, że koszt jednego filmu z krajów kapitalistycznych wahał się średnio od 3000 do 5000 dolarów ${ }^{18}$. Po drugie, ograniczenie w ramówce tytułów z Zachodu i radykalne zwiększenie liczby tytułów z bloku wschodniego miało również cel propagandowy; w ten sposób władza wskazywała na zacieśnianie przyjaźni z bratnimi krajami. Po trzecie, wpływ na sytuację miał również bojkot telewizji przez środowisko aktorskie, polegający na konsekwentnej odmowie współpracy przy realizacji seriali, filmów telewizyjnych i spektakli teatru telewizji ${ }^{19}$. Odbił się on jednak przede wszystkim na obecności na ekranach rodzimych produkcji - telewizja nie mogła produkować takiej liczby nowych filmów i seriali, na jakie miała zapotrzebowanie. Braki uzupełniała więc dostępnymi pozycjami z krajów socjalistycznych. 
Prowadzona przez władzę narracja wokół obecności filmów w telewizji nie była spójna. W prasie najchętniej pisano o kryzysie. Z wielkiej liczby powtórek i braku atrakcyjnych dla widzów filmów gatunkowych tłumaczono się przede wszystkim brakiem dewiz i ogólnie złą sytuacją gospodarczą. Natomiast podczas zamkniętych posiedzeń komitetów nikt o trudnościach finansowych nie mówił, za to chętnie odwoływano się do celów propagandowych, odnajdując w zmianie proporcji między filmami zachodnimi i socjalistycznymi dowód na powrót na właściwy kurs edukacji społeczeństwa oraz zacieśniania więzi z bratnimi krajami.

Głosy na temat kryzysu ekonomicznego pojawiały się w prasie również ze strony publicystów. Barbara Kaźmierczak na łamach „Ekranu” pisała w listopadzie 1982 r., iż nie da się ukryć, że $i$ w kulturze, $i$ w telewizji idzie dziś przede wszystkim o pieniądze ${ }^{20}$. Z kolei Maria Rajczuk w tekście publikowanym w tym samym piśmie w styczniu 1983 r. zauważyła, że skłonność władzy do zastępowania tytułów zachodnich filmami socjalistycznymi brała się także z tego, że w przypadku tych drugich dysponowano licencjami nieograniczonymi czasowo ${ }^{21}$. Publicystka sugerowała przy tym, że kraje zachodnie przynajmniej na jakiś czas narzuciły na Polskę embargo na zakup filmów: Telewizja Polska otrzymała pieniądze na zakup nowych filmów, a kilka firm zachodnich wyraziło zgodę na ponowna wspótprace z Polską. Mimo to wiele filmów z drugiego obszaru płatniczego nigdy nie trafi do naszej telewizji przede wszystkim dlatego, że sa zbyt dro$g^{22}$. O takich sankcjach wspomina również Pikulski. To spowodowało też problemy z naprawą sprzętu technicznego, nie było bowiem możliwości ściągnięcia z Zachodu części zamiennych, co zmuszało techników do szukania zamienników na stołecznym targowisku - Wolumenie ${ }^{23}$.

W wypowiedziach decydentów zrzucających całą winę za zły program telewizyjny na kwestie gospodarcze można dostrzec uprawianą przez władzę już od połowy 1981 r. propagandę klęski ${ }^{24}$. Mówiło się o niekorzystnej sytuacji gospodarczej kraju, spychając odpowiedzialność na poprzednią ekipę rządzącą, a personalnie na internowanego w stanie wojennym Edwarda Gierka. Przede wszystkim jednak za kryzys winiono przywódców „Solidarności”, rzekomo odpowiedzialnych za destabilizację kraju. Strategia ta wpisywałaby się w długą tradycję polskiej władzy, która, jak zauważył Edward Zajiček, chętnie sięgała po argumenty ekonomiczne, uzasadniając w ten sposób konieczność eliminacji niecenzuralnych treści ${ }^{25}$.

By oddać charakter wypowiedzi prasowych reprezentantów władzy na temat ramówki, przytoczę słowa dwóch decydentów wydrukowane w pierwszym numerze „Anteny” po wznowieniu jej wydawania w maju 1982 r. Władysław Loranc, przewodniczący Radiokomitetu (Komitetu ds. Radia i Telewizji), w tekście na pierwszej stronie czasopisma prosił widzów o wyrozumiałość względem ubogiego programu: W tym miejscu raz jeszcze podkreślę, że PR $i$ TV w roku bieżacym działaja w sytuacji ograniczonych możliwości produkcyjnych $i$ handlowych, co oznacza, że czesść oczekiwań nie pozostanie spetnionych. Trudności dotycza zwłaszcza programów artystycznych, w tym rozrywkowych i filmowych. Czynimy starania, by poprawić ten stan rzeczy $w$ oparciu o interesujace $i$ wartościowe pozycje z krajów socjalistycznych. Sadzimy, że i nasza własna twórczość artystyczna zdoła przezwycięzyć impas i przedstawi widzom oraz stuchaczom nowe, godne uwagi realizacje $^{26}$. Tym impasem miał być z pewnością wspomniany już bojkot aktorski, skutecznie uniemożliwiający telewizji produkowanie własnych audycji. 
Andrzej Kurz, zastępca przewodniczącego Radiokomitetu, w bardzo podobnym tonie tłumaczył się dziennikarzowi z braku najpopularniejszych gatunków, czyli westernów, kryminałów i komedii. On również wskazywał na problemy natury ekonomicznej, w szczególności na brak dewiz. Wspomniał przy tym o gigantycznych długach pozostawionych przez poprzednią ekipę kierującą telewizją, które były efektem nieodpowiedzialnej polityki zakupów i układania programu. Interesujące, że zarysował również możliwy plan naprawczy, który pozwoliłby wyjść z impasu finansowego - ostatecznie okazał się on jednak mało realny. Mówił, że szansą może być eksport rodzimych produkcji telewizyjnych na Zachód. Przeszkodą w realizacji tego celu miał być jednak brak funduszy na importowanie z krajów kapitalistycznych kolorowej taśmy niezbędnej do kręcenia filmów i seriali o odpowiedniej jakości technicznej. W konsekwencji, jak mówił, polska telewizja została wpędzona w swojego rodzaju kwadraturę koła ${ }^{27}$.

Zupełnie inny obraz wyłania się z protokołów zamkniętych posiedzeń partyjnych z czasu stanu wojennego. Na przykład podczas zebrania Komitetu ds. Radia i Telewizji w marcu 1982 r. zwrócono uwagę na konieczność zwiększenia w ramówce procentu filmów z krajów socjalistycznych ${ }^{28}$. Sugerowałoby to, że owa konieczność nie brała się w tym przypadku z braków finansowych, lecz raczej z przesłanek propagandowych.

Jeszcze mocniej powiązanie zmian w programie z wymogami ideologicznymi wybrzmiało na VII Plenum KC PZPR w marcu 1982 r., gdzie kierownictwo telewizji jednoznacznie wskazywało, że należy zmienić treść $i$ styl kultury narodowej, aby odpowiadała ona dopiero rozpoczętej emancypacji robotników i chłopów ${ }^{29}$. Zauważono jednocześnie, że podjęto już pierwsze kroki w tym kierunku - taką słuszną zmianą miało być właśnie odwrócenie proporcji w ramówce między tytułami z krajów socjalistycznych a tymi z krajów kapitalistycznych, które miały reprezentować kulturę elitarną, intelektualną i opartą na wzorach szlacheckich ${ }^{30}$. W innym dokumencie z marca tego roku (Tezy na naradę aktywu Polskiego Radia i Telewizji „,Nasze zadania po VII Plenum KC PZPR”) również znalazła się wzmianka o wprowadzonych „słusznych” korektach w programie. Autor pisał, że w programie radiowo-telewizyjnym dokonaliśmy już słabszych zmian w proporcjach między materiałami pochodzacymi z krajów kapitalistycznych a materiałami z krajów socjalistycznych. Tych drugich jest więcej. Tę tendencję powinniśmy zdecydowanie utrzymać, by dla otwartej polityki kulturalnej zachować mocny fundament, ważny z ustrojowego punktu widzenia interesów klasy robotniczej ${ }^{31}$. Rok później, w marcu 1983 r., sekretarz KC przy Radiokomitecie Stefan Olszowski mówił na jednej z narad, że zadaniem telewizji jest zarówno demaskowanie antykomunistycznych ośrodków dywersyjnych, jak i przekonywanie społeczeństwa, że jedynym sojusznikiem Polski jest blok socjalistyczny

32. Temu celowi miały służyć również emisje filmów sprowadzanych z naszych bratnich krajów - obrany przez władzę kurs był niezmienny w czasie trwania stanu wojennego, również po jego zawieszeniu 31 grudnia 1982 r.

\section{Bez licencji, czyli o potrzebie „filmów relaksowych"}

Powyższe wypowiedzi, w których nawet nie wspomina się o ograniczonych możliwościach finansowych telewizji, za to wiele mówi się o potrzebie zacieśniania stosunków z blokiem wschodnim i reedukacji społeczeństwa, mogłyby dowodzić, że 
brak dewiz był nawet ówczesnej władzy na rękę. Dzięki temu mogla tłumaczyć się na dodatek nie kłamiąc - z nieobecności najbardziej pożądanych filmów, odwołując się do problemów finansowych, a w rzeczywistości wprowadzać tytuły socjalistyczne w celach czysto propagandowych. Byłaby to jednak teza upraszczająca sprawę. Władza była niejako zmuszona do podjęcia tej podwójnej gry $\mathrm{z}$ widzami, choć uświadomiła to sobie dopiero pod koniec 1982 r. Z jednej strony bowiem zależało jej na systematycznym kreowaniu określonego wizerunku „Solidarności” i podtrzymywaniu przekonania w społeczeństwie o złej sytuacji w kraju. Z drugiej jednak w pewnym momencie musiała uświadomić sobie, że skuteczną propagandę może prowadzić tylko wtedy, gdy telewizja będzie faktycznie oglądana i to na dodatek z przyjemnością. A będzie oglądana tylko wtedy, gdy spełni potrzeby telewidzów.

Tę myśl znakomicie wyraził podczas narady w Grzegorzewicach Jerzy Bajdor, który jesienią 1982 r. zastąpił Władysława Loranca na stanowisku dyrektora generalnego w Komitecie ds. Polskiego Radia i Telewizji. Fragment tego przemówienia opublikowano na łamach „Anteny”. Dyrektor stwierdzał w nim, że przesunięcie akcentów programowych na korzyść filmów polskich i socjalistycznych nie jest zabiegiem doraźnym, lecz trwałym elementem polityki programowej, spetniajacym określona ideowo funkcję umacniania socjalistycznego charakteru naszej wspótczesnej kultury ${ }^{33}$. Zaznaczył przy tym: Nie możemy jednak popadać w grzech jednostronności i doktrynerstwa. Oczekiwania i potrzeby wielomilionowej widowni telewizyjnej sa i będa różnorodne. Pozycje lżejsze, relaksowe, musza być - rzecz jasna - w repertuarze obecne (...). Kino krajów socjalistycznych jest dość ubogie $w$ gatunki rozrywkowo-sensacyjne i samo nie zdoła wypetnić tej luki. Dlategomimo wszystkich ekonomiczno-finansowych trudności państwa-uzasadniony wydaje sie postulat, aby jakieś rozsądne minimum środków przeznaczyć na zakup filmów z drugiego obszaru płatniczego. Oczywiście musi przy tym obowiąywać zasada starannej selekcji, ostrej eliminacji wszelkiej tandety ${ }^{34}$. Takie podejście, równoważące propagandę i rozrywkę, miało odróżniać Bajdora od Loranca, który był zbyt pryncypialny nawet dla swoich zwierzchników ${ }^{35}$. Jego sumienność w zmianie proporcji między tytułami z Zachodu i krajów socjalistycznych doprowadziła do tego, że telewizja stała się niepopularna, a na to partia nie mogła sobie pozwolić. Po pewnym czasie zrozumiano, że chcąc osiągnąć nadrzędny cel poprawiania nastrojów społecznych, telewizja musi sięgnąć po atrakcyjne filmy, również z Zachodu.

Z wypowiedzi Bajdora można wywnioskować, jaki profil filmów był według władzy najbardziej pożądany przez telewidzów. Były to pozycje gatunkowe, rozrywkowe, na dodatek zachodnie - bo właśnie tam, według decydentów, powstawały najlepsze produkcje spełniające to kryterium. Analiza programu telewizyjnego z okresu stanu wojennego pokazuje jednak, że nawet po zmianie kierownictwa komitetu nie korzystano w pełni z tej wiedzy. Władza co prawda rzeczywiście starała się stawiać na produkcje rozrywkowe, lecz niekoniecznie te pochodzenia zachodniego. Brak tego rodzaju filmów starano się maskować tytułami z krajów socjalistycznych, co nie zaspokajało zapotrzebowania telewidzów. Według relacji Pikulskiego kierownictwo było tak zdeterminowane w poszukiwaniu amerykańskich filmów gotowych do emisji, że z zapałem przeczesywało swoje archiwa, czasami nawet nie zważając na to, że na niektóre tytuły skończyły się licencje. Miało się ponoć zdarzać, że rozsądek przegrał z zacietrzewieniem - dlatego też, nie myśląc o konsekwencjach finansowych, decydowano się na emisję takich filmów ${ }^{36}$. 
Narzekanie na program było powszechne i niezmienne przez cały okres stanu wojennego, a nawet długo po jego zakończeniu, o czym świadczą choćby przywołane wypowiedzi przedstawicieli władzy: Loranca, Kurza czy Bajdora. Dodać do nich można również głos dziennikarki Elżbiety Fąfrowicz, która choć broniła ramówki, na początku cytowanego już tekstu stwierdzała: mówi się o programie telewizyjnym, że jest zły. Nawet zaprzyjaźnione radio $w$ audycji „Wesoły autobus" natrzasało się ostatnio z tego, że filmy sq okropne ${ }^{37}$. Takich opinii było wiele, mimo że ostatecznie w programie nie brakowało kina rozrywkowego czy - jak określił je Bajdor - relaksowego. Jeśli bowiem spojrzy się na Wykres 5., przedstawiający strukturę gatunkową programu telewizyjnego, to okaże się, że co prawda bezapelacyjnie najliczniejszymi tytułami były te określane mianem dramat/film obyczajowy ${ }^{38}$, jednak zaraz za nimi plasowały się produkcje opisane jako komedie, romanse, kryminały, przygodowe, familijne i sensacyjne, czyli filmy typowo rozrywkowe. Widownia spragniona tytułów „,relaksowych” powinna być więc zadowolona. Dlaczego tak jednak nie było? Odpowiedź wydaje się prosta. Widownia potrzebowała nie tylko filmów rozrywkowych, ale filmów rozrywkowych z krajów zachodnich. Tymczasem w repertuarze telewizji propozycje tego typu były w znacznej mierze produkcji socjalistycznej. Komedie pochodziły przede wszystkim z Czechosłowacji (aż 42 tytuły, za nimi uplasowały się ex aequo ZSRR i USA ${ }^{39} \mathrm{z} 22$ tytułami), natomiast większość innych filmów, które można określić jako rozrywkowe, dostarczał Związek Radziecki. Przewaga obrazów z tego kraju była zauważalna szczególnie w przypadku romansów (18 - ZSRR, 9 - USA), kryminałów (11 - ZSRR, 5 - Francja) i filmów przygodowych (16 - ZSRR, 4 - USA ${ }^{40}$. Nie dziwi więc, że tak skonstruowana ramówka nie cieszyła się popularnością.

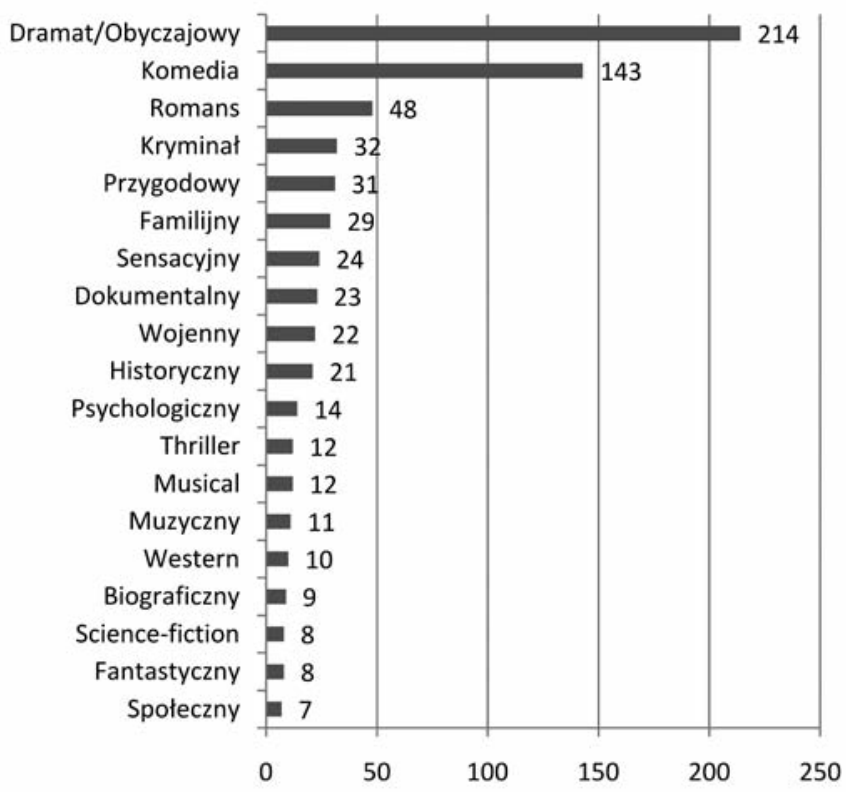

Wykres 5. Struktura gatunkowa filmów zagranicznych emitowanych w stanie wojennym (uwzględniono gatunki, które pojawiły się co najmniej siedmiokrotnie). $\mathrm{n}=678$ określeń gatunkowych 


\section{Kino nowej pamięci, czyli przeciwko piórom w pupach}

Jeśli spojrzeć na strukturę gatunkową ramówki, może dziwić tak skąpa obecność na ekranach telewizorów filmów reprezentujących kino wojenne. Trwał przecież stan wojenny, więc mogłoby się wydawać, że w ramówce powinno być zarezerwowane specjalne miejsce dla tego typu kina. I tak było, lecz włodarze telewizji sięgali raczej po filmy wojenne rodzimej produkcji, o odpowiednim wydźwięku ideologicznym. W grupie polskich filmów emitowanych w stanie wojennym (zob. Wykres 6) kino wojenne zajmuje wysoką, bo czwartą pozycję, zaraz za filmami obyczajowymi, komediami i filmami psychologicznymi.

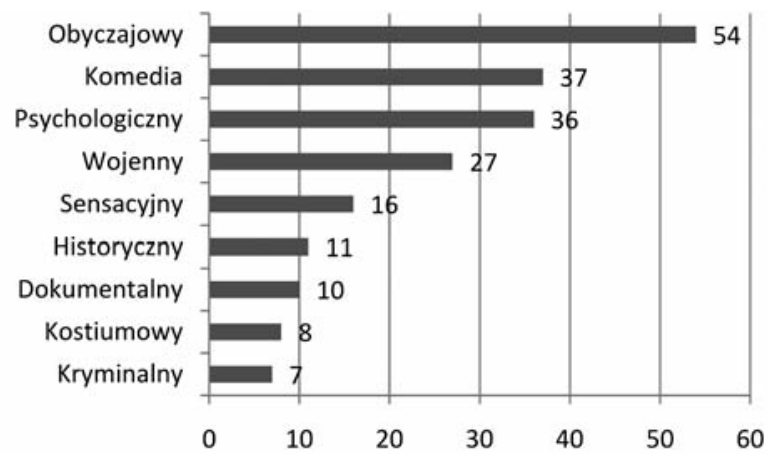

Wykres 6. Struktura gatunkowa polskich filmów emitowanych w stanie wojennym (uwzględniono gatunki, które pojawiły się co najmniej siedmiokrotnie). $\mathrm{n}=206$ określeń gatunkowych

Kino historyczne, w tym wojenne, było w tamtym czasie dla decydentów szczególnie ważne. Dał temu wyraz Jerzy Bajdor, mówiąc w przytaczanym już wystąpieniu, że walka o rozumienie historii, o jej wtaściwa interpretację, jest bardzo istotnym fragmentem szerszej batalii o świadomość społeczna. Dlatego téz polityka programowa telewizji - kontaktujacej się codziennie z wielomilionowa widownia - musi być $w$ stosunku do tematu historycznego oparta o zasadę wnikliwego wyboru tych treści i tych postaw, które sa szczególnie żywotnym i ważnym dla wspótczesności elementem naszej tradycji ${ }^{41}$. W podobnym tonie wypowiadała się publicystka „Anteny”, Elżbieta Fąfrowicz, która w polskich filmach wojennych, pokazywanych wówczas w telewizji, dostrzegła znamiona przemyślanego i potrzebnego procesu edukacji młodego widza, do tej pory historię poznającego jedynie z podręczników szkolnych i opowiadań rodziców ${ }^{42}$.

Filmy te, podobnie jak pozostałe polskie produkcje i tytuły importowane z krajów socjalistycznych, miały być dostosowane do wymagań czasów i odpowiednio kształtować postawy, szczególnie wśród młodzieży. Fąfrowicz wymienia konkretne tytuły, jakie miały we właściwy sposób edukować społeczeństwo: Godziny nadziei Jana Rybkowskiego, Hubal (1973) Bohdana Poręby, Ciemna rzeka (1973) Sylwestra Szyszko, Ocalić miasto (1976) Jana Łomnickiego oraz Skapani w ogniu (1963), Ostatnie dni (1969), Kierunek Berlin (1968) i Barwy walki (1964) Jerzego Passendorfera. Dla Fąfrowicz właśnie te filmy oraz kilka innych tytułów ${ }^{43}$ miały być właściwą i z utęsknieniem wyczekiwaną alternatywą dla świata różowych telefonów i piór $w$ pupach ${ }^{44}$, który według publicystki był do tej pory propagowany w telewizyjnej ramówce. 
Wizja historii wyłaniająca się z wymienionych filmów jest oczywista. Nie było w czasie stanu wojennego miejsca na pozycje z polskiej szkoły filmowej, za to wyjątkowo chętnie emitowano dzieła Jerzego Passendorfera (pięć jego filmów pojawiło się w ramówce) czy Ewy i Czesława Petelskich (osiem filmów w ramówce ${ }^{45}$; razem z Jerzym Zarzyckim byli autorami największej liczby produkcji pokazywanych w stanie wojennym). Filmy te należały do grupy tytułów składających się na kino nowej pamięci, jak nazwał je Piotr Zwierzchowski ${ }^{46}$. Chętnie wykorzystywały widowiskowość kina batalistycznego, by opowiadać o II wojnie światowej zgodnie z oficjalną linią partii. Jak pisze Zwierzchowski, jednym z ich podstawowych celów była po prostu legitymizacja systemu ${ }^{47}$.

\section{Stare i nowe, czyli w poszukiwaniu filmów premierowych}

Wspominałem już, że władza doskonale zdawała sobie sprawę, iż proponowany program telewizyjny nie cieszył się popularnością u widzów, o czym świadczą choćby przytoczone apele o wyrozumiałość. W wypowiedziach reprezentantów partii głównym zarzutem wobec ramówki był brak filmów premierowych. Sugerowano tym samym, że program składa się z filmów doskonale znanych i wielokrotnie powtarzanych, a więc nienowych. Co ciekawe, nie do końca było to prawdą. Wykres 7. dobrze pokazuje, że zdecydowanie najwięcej (50 proc.) emitowanych filmów powstało w ciągu zaledwie pięciu poprzednich lat, co nawet wedle współczesnych standardów byłoby wynikiem zadowalającym. Warto dodać, że aż 81 proc. wszystkich pokazywanych w telewizji tytułów wyprodukowano w poprzednich dziesięciu latach.

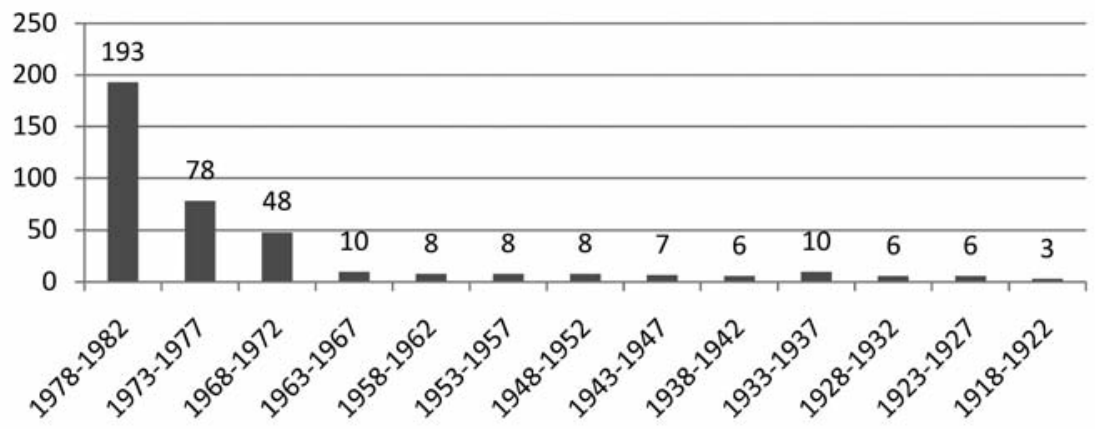

Wykres 7. Liczba filmów zagranicznych emitowanych w telewizji w stanie wojennym z podziałem na lata produkcji (uwzględnia tylko filmy ze zidentyfikowaną datą produkcji). $\mathrm{n}=391$ filmów

Skąd więc niezadowolenie widowni, a także samych decydentów? Odpowiedzi można szukać w danych przedstawionych na Wykresie 8. Pokazuje on, z jakich krajów pochodziły najnowsze tytuły. Nie ma wątpliwości, że przewaga filmów socjalistycznych z lat 1968-1982 była ogromna, choć różnica między produkcjami socjalistycznymi i zachodnimi z każdego kolejnego przedziału czasowego się zmniejsza. Aż w końcu filmy zachodnie zaczynają dominować nad filmami socjalistycznymi, jeśli brać pod uwagę produkcje z lat 1918-1962. Z wykresu wynika więc, że za najnowsze produkcje odpowiadały kraje socjalistyczne, a za starsze, 
najczęściej przedwojenne - kraje kapitalistyczne. To tłumaczyłoby niechęć widzów do propozycji programu telewizyjnego, mimo że ten składał się głównie ze względnie nowych produkcji. Widzowie oczekiwali więc w pierwszej kolejności filmów zachodnich i to niekoniecznie nowych. Optymalnym punktem programu byłby zaś film zarówno pochodzący z Zachodu, jak i premierowy.

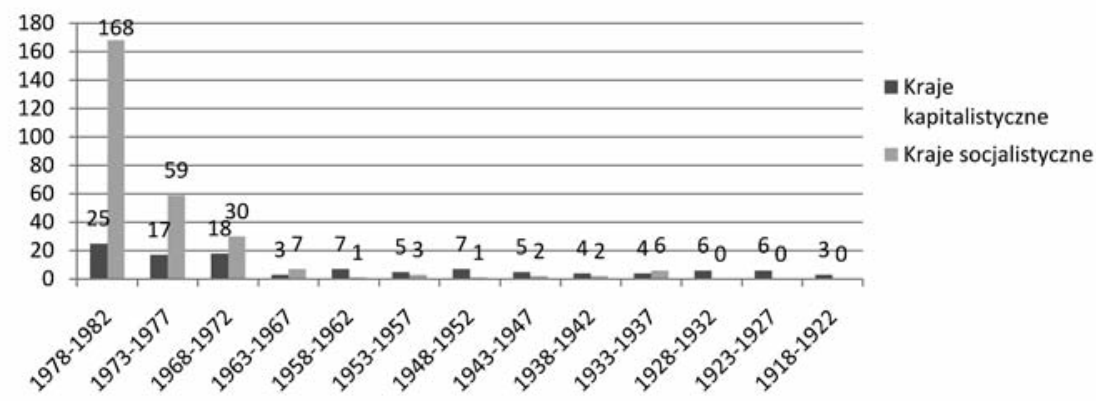

Wykres 8. Liczba filmów zagranicznych z krajów kapitalistycznych i socjalistycznych (w przypadku danych sprzed 1945 r. podział umowny, do kapitalistycznych zaliczam Francję, USA, Włochy i Anglię, a do socjalistycznych - ZSRR) emitowanych w telewizji w stanie wojennym z podziałem na lata produkcji (uwzględnia tylko filmy ze zidentyfikowaną datą produkcji). $\mathrm{n}=389$ filmów

Paradoksalnie, przeklinane przez widzów i władzę powtórki dotyczyły więc w przeważającej mierze filmów zachodnich, i to przede wszystkim produkcji amerykańskiej. Jeśli zwrócimy uwagę na daty powstania filmów pochodzących z dwóch kinematografii Zachodu najliczniej reprezentowanych na polskich ekranach telewizyjnych, czyli z Francji i Stanów Zjednoczonych (zob. Wykres 9), to okaże się, że nowsze tytuły były produkcji francuskiej, natomiast te amerykańskie zrealizowano głównie przed wojną i były to w większości filmy dwóch autorów - Charliego Chaplina i Harolda Lloyda. W telewizji w tym okresie pokazano aż sześć Chaplinowskich filmów pełnometrażowych ${ }^{48}$ i dwanaście krótkich. Równie chętnie emitowano tytuły z Lloydem - w ramówce znalazło się ich aż piętnaście. Można więc zaryzykować tezę, że telewidzowie pożądali nie tyle filmów zachodnich, ile filmów produkcji amerykańskiej, których wśród nowości niemal w ogóle nie było.

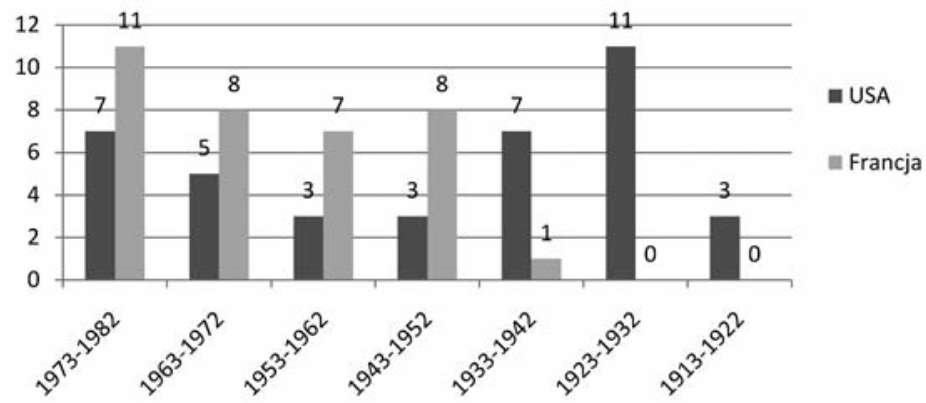

Wykres 9. Liczba filmów z USA i Francji emitowanych w telewizji w stanie wojennym z podziałem na lata produkcji (uwzględnia tylko filmy ze zidentyfikowaną datą produkcji). $\mathrm{n}=74$ filmy 
Opinia włodarzy, uważających powtórki za największą bolączkę programu telewizyjnego, stoi również w sprzeczności z wynikami analizy ramówki z listopada 1981 r. (Wykres 10), czyli sprzed interesującego mnie okresu. Okazuje się bowiem, że w tym czasie wcale nie pokazano filmów nowszych niż w stanie wojennym. Wręcz przeciwnie, tak chwalony i lubiany program, na który składało się, przypomnijmy, 50 proc. filmów i seriali z krajów zachodnich, miał do zaoferowania filmy starsze od pokazywanych między 13 grudnia 1981 r. a 22 lipca 1983 r. Wśród nich zaledwie 18 proc. zostało wyprodukowanych w poprzednich pięciu latach, natomiast aż 36 proc. powstało przed $1968 \mathrm{r}$.

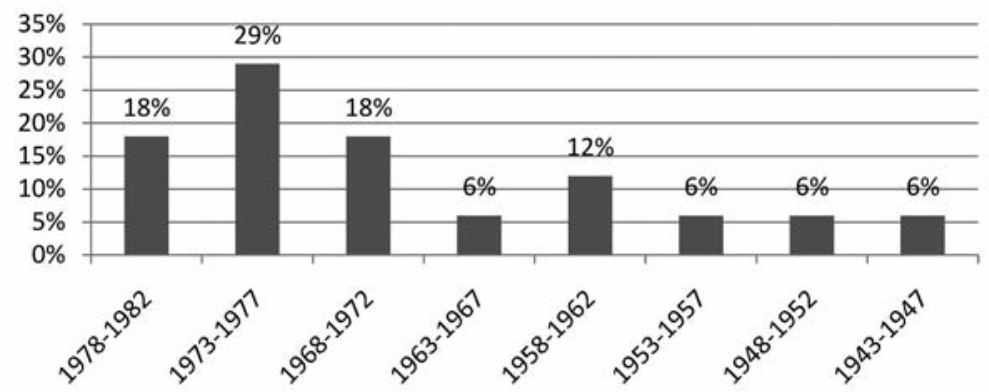

Wykres 10. Procentowa struktura programu telewizyjnego z listopada 1981 r. z podziałem na lata produkcji emitowanych filmów zagranicznych (uwzględnia tylko filmy ze zidentyfikowaną datą produkcji). $\mathrm{n}=100 \%$

Jeśli faktycznie upatrywać głównego problemu ramówki w braku tytułów premierowych, to dotyczył on raczej filmów i seriali z Polski. Na wykresie pokazującym statystykę lat produkcji emitowanych dzieł (zob. Wykres 11) widać, że filmy z lat 1968-1982 nie dominowały nad pozostałymi w takim stopniu, jak to miało miejsce w przypadku tytułów zagranicznych. Na taki stan rzeczy z pewnością miał wpływ wspomniany bojkot, który ograniczył możliwości realizacji filmów telewizyjnych, a w szczególności seriali, co dało o sobie znać w stanie wojennym, ale w jeszcze większym stopniu już po jego zakończeniu. Po 13 grudnia dysponowano jeszcze świeżymi tytułami; do takich nowości należał choćby przebój początku lat 80. - debiutujący w październiku 1982 r. serial Jan Serce (1981) Radosława Piwowarskiego.

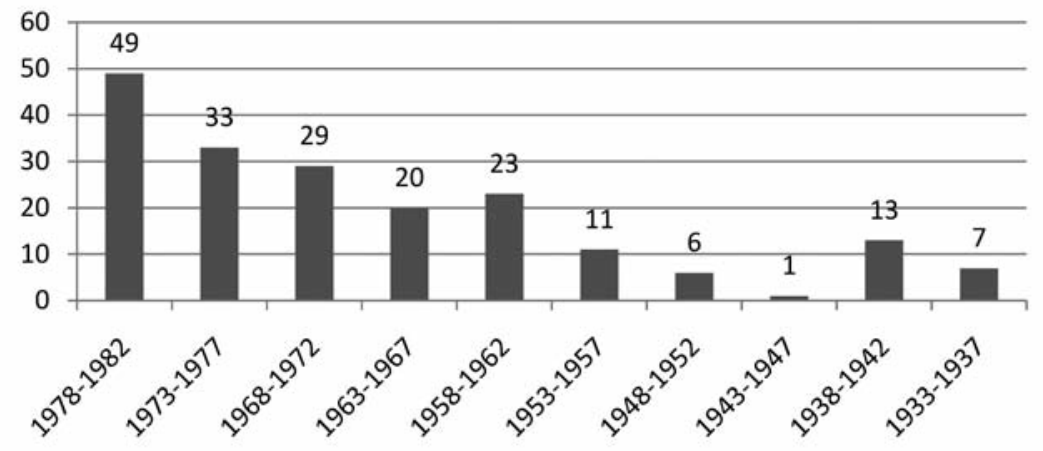

Wykres 11. Liczba polskich filmów emitowanych w telewizji w stanie wojennym z podziałem na lata produkcji. $\mathrm{n}=192$ filmy 


\section{Optymistyczny paradoks, czyli przypadek Swobodnego jeźdźca}

Włodarze telewizji odpowiedzialni za programowanie byli świadomi, że muszą ułożyć atrakcyjną ramówkę jak najniższym kosztem. Byli więc w stanie sięgnąć nawet po filmy nieoczywiste, które wymagały od komentatorów dużej pracy interpretacyjnej, pozwalającej wyjaśnić ich obecność w tak bardzo zideologizowanej telewizji. Takim przypadkiem jest Swobodny jeździec Dennisa Hoppera. Pierwotnie, przed wprowadzeniem stanu wojennego, jego emisja była planowana na 19 grudnia 1981 r. Z oczywistych względów film nie został pokazany, ale nie zrezygnowano z tego tytułu. Na ekranach telewizorów pojawił się 13 maja $1982 \mathrm{r}$.

Stan wojenny nie kojarzy się z czasem, w którym mogłyby się pojawić - czy to w kinie, czy w telewizji - produkcje wcześniej niedopuszczone do publicznej prezentacji ${ }^{49}$. Dlatego przypadek filmu Hoppera wydaje się szczególny, bowiem wcześniej został aż dwukrotnie zablokowany przez cenzurę. W 1971 r. nie otrzymał zgody na rozpowszechnianie w kinach ${ }^{50}$, a w 1977 r. nie udzielono pozwolenia na emisję Naczelnej Redakcji Programów Filmowych TV ${ }^{51}$. W obu przypadkach powoływano się na tę samą przyczynę, czyli przedstawianie ruchu hippisowskiego w pozytywnym świetle, a dokładnie na wskazywanie na wyższość intelektualna i racje moralne wypowiedziane przez hippisów ${ }^{52}$. Ten argument cenzora może zaskakiwać. Trudno bowiem Swobodnego jeźdźca uznać za dzieło jednostronnie gloryfikujące kontrkulturę, o czym pisał Konrad Klejsa: Zbyt wiele jest $w$ tym filmie dziwnych motywów $i$ wątków, by uznać go za jednoznaczna apologię kontestacyjnego ży $\mathrm{cia}^{53}$. Nie były to jednak jedyne zastrzeżenia, jakie cenzura miała do filmu Hoppera. Dla władzy był to szczególnie jaskrawy przykład filmu szkodliwego z powodów obyczajowych, choć trzeba przyznać, że stosunek samego cenzora do filmu był wyjątkowo przychylny. Cenzor pisał na przykład, że bohaterowie Hoppera i Fondy to mili i przyzwoici chłopcy, budzacy od pierwszego do ostatniego ujęcia $w$ filmie szczera sympatię. Chłopcy ci prezentuja się wspaniale na swych nowoczesnych motorach, którymi przemierzaja Stany ${ }^{54}$. Mimo to jeszcze w notatce z 8 marca 1979 r. opisano Swobodnego jeźdźca jako dzieło, którego nie dopuszczono do emisji ze względu na to, że popularyzowat narkomanię, zawierat sceny erotyczne rozgrywajace się na cmentarzu $i$ w kościele ${ }^{55}$.

Co więc takiego się wydarzyło, że dwa lata później uznano film Hoppera za nieszkodliwy i to nawet po wprowadzeniu stanu wojennego? Pierwszym powodem było prawdopodobnie to, na co zwróciła uwagę Bogumiła Michalska: Swobodny jeździec został zakupiony jeszcze przed decyzją cenzury - i to nie przez Centralę Wynajmu Filmów, lecz właśnie przez telewizję ${ }^{56}$. Władze dysponowały więc licencją, pieniądze zostały wydane (Budzyński w „Antenie” pisał o kwocie 5000 dolarów ${ }^{57}$ ), Filmowa Rada Repertuarowa CWF-u jednogłośnie przyjęła film, oceniając go nie tylko jako wybitne dzieło sztuki, ale gtęboki $i$ wstrzasajacy obraz relacji hippisów $i$ wrogości do nich otoczenia ${ }^{58}$, cenzura zaś dwukrotnie kierowała go na półkę. Według Michalskiej w 1982 r. mijał okres licencji na film, więc władze miały dwa wyjścia - albo być konsekwentnym i pozwolić, by znany z relacji w prasie branżowej ${ }^{59}$ film ,zmarnował się”, albo zrewidować swój pogląd i wykorzystać oczekiwany tytuł, by wzbogacić nisko oceniany program telewizyjny o pozycję szczególnie pożądaną, bo amerykańską, na dodatek premierową, mimo że powstałą ponad dziesięć lat wcześniej. 
Choć władze ugięły się, zważając zapewne na okoliczności - słaby program, brak pieniędzy na nowe produkcje, konieczność sięgania do archiwów - dzieło Hoppera nadal było dla niej trudne do zaakceptowania. Michalska relacjonuje, że przed emisją film został mocno pocięty przez cenzurę, która nakazała usunąć między innymi sławną psychodeliczną scenę na cmentarzu ${ }^{60}$. Być może dopiero wtedy, gdy ruch hippisowski był już tylko wspomnieniem, można było mówić o nim bardziej otwarcie.

Stosunek władzy do kontrkultury był już jednak wcześniej ambiwalentny. Z jednej strony można ją było wykorzystać jako wyraz sprzeciwu wobec zgnilizny moralnej zachodnich społeczeństw, ale z drugiej była groźna jako ewentualna inspiracja dla rodzimej młodzieży ${ }^{61}$. Można przypuszczać, że gdy amerykańskie ruchy kontestacyjne powoli przechodziły do historii, stawały się dla władzy mniej groźne, a nabywały atrakcyjności jako pretekst do krytyki kultury zachodniej. Prawdopodobnie stąd wzięła się zgoda na emisję. Gdy nie można już było posądzić nikogo o propagowanie idei kojarzonych z amerykańską kontrkulturą ${ }^{62}$, film Hoppera był idealny, by obnażyć, jak pisał jeden z recenzentów, najciemniejsze strony amerykańskiej prowincjonalnej mentalności. Mentalności pachnacej średniowieczem i inkwizycja ${ }^{63}$.

Ostatecznie więc emisja Swobodnego jeźdźca w tak newralgicznym okresie, jak stan wojenny, wcale nie wydaje się aż tak irracjonalna. Po pierwsze, film mógł zostać wykorzystany w walce ideologicznej ze Stanami Zjednoczonymi, w tamtym czasie szczególnie mocno krytykującymi Polskę. Po drugie, dzięki premierowemu pokazowi oczekiwanego, a wcześniej nieprezentowanego w kinach amerykańskiego filmu można było wzbogacić ramówkę. Władza przedstawiła się przy tym jako elastyczna, skłonna do weryfikacji wcześniejszych decyzji.

Cel został osiągnięty. Rezonans wywołany emisją był duży. Jak relacjonuje Michalska, telewidzowie pisali listy do telewizji i gazet z prośbą o powtórkę. Film spotkał się również z dobrym odbiorem krytyków. Autorka przywołuje głosy Andrzeja Kołodyńskiego i Agnieszki Osieckiej ${ }^{64}$. Do nich można dołączyć przytaczaną recenzję Budzyńskiego, który pisał, iż dobrze się stało, że wydatek sprzed kilku lat $w$ wysokości 5 tysięcy dolarów (tyle kosztowat zakup „Easy Ridera”) nie podzielit losu innych, znacznie droższych zakupów dewizowych, które gdzieś się zapodziały. Widzowie mieli okazję zobaczyć ciekawy film. Lepiej późno niż wcale. To, że pokazano go właśnie teraz, można nazwać optymistycznym paradoksem ${ }^{65}$.

Cytat ten wydaje się wyjątkowo symptomatyczny. Nie tylko wskazuje na paradoks emisji filmu w tak wyjątkowym momencie, ale również zwraca uwagę na irracjonalność systemu komunistycznego w kwestii polityki dystrybucyjnej. Wypowiedź ta bowiem sugeruje, że licencje na konkretne tytuły kupowano przed decyzją cenzury, która niekiedy sprawiała, że pozyskane filmy, często za znaczne kwoty, gdzieś się, jak to eufemistycznie ujął recenzent, ,zapodziewały”. Ale to także dowodzi, że w stanie wojennym polska telewizja nie mogła sobie pozwolić na takie marnotrawstwo i nawet zakupy wcześniej uznane za problematyczne postanowiono wykorzystać. 
Filmy w stanie wojennym miały do odegrania w telewizji niezwykle ważną rolę. Z początku miały budować - wespół z umundurowanymi spikerami i wojskową publicystyką - atmosferę militaryzacji, powagi, może nawet psychozy. $\mathrm{Z}$ czasem jednak, gdy władza postawiła na tonowanie emocji, ich celem było poprawianie nastrojów społecznych, a także wspieranie celów propagandowych. Szczególną rolę w tym procesie odgrywały filmy zagraniczne. Zwiększenie liczby tytułów z państw socjalistycznych miało wskazywać na zacieśnianie przyjaźni z bratnimi krajami. Od filmów zachodnich oczekiwano natomiast rozrywki. Nie było ich jednak wystarczająco dużo z powodu braku dewiz. Taki program nie spotkał się z dobrymi opiniami widzów, którzy zdążyli się już przyzwyczaić do zupełnie innej ramówki, złożonej głównie z dzieł zachodnich, dominujących w telewizji w końcówce lat 70. Na dodatek czasy się zmieniały, a wraz z nimi technologia. Do Polski docierały pierwsze magnetowidy, a te umożliwiały kontakt z najbardziej upragnionymi filmami z Zachodu, przy których propozycje polskiej telewizji wypadały wyjątkowo nieatrakcyjnie.

MiCHAŁ PIEPIÓRKA

Artykuł powstał w ramach realizacji projektu „Rozpowszechnianie filmów w Polsce w latach 1945-1989", finansowanego przez Narodowe Centrum Nauki (2016/22/E/HS2/00135).

${ }^{1}$ Ta luka ma z pewnością wiele wspólnego z głębszym problemem, o którym pisał Andrzej Gwóźdź. Apelował on, by powstała na polskim gruncie „medialna historia filmu”, która opisywałaby nie tylko kinowe życie fil$\mathrm{mu}$, ale jego długie trwanie w różnych mediach, w tym w telewizji (A. Gwóźdź, $D V D$ jako para medium kina, czyli historia filmu po nowemu (na przykładzie filmów Kazimierza Kutza), w: Kino polskie: reinterpretacje. Historia - ideologia - polityka, red. K. Klejsa, E. Nurczyńska-Fidelska, Wydawnictwo Rabid, Kraków 2008, s. 489).

${ }^{2}$ Program telewizyjny w „Trybunie Ludu” pojawił się dopiero 16 grudnia. Dane na temat ramówki trzech pierwszych dni stanu wojennego zaczerpnąłem ze strony staratelewizja.fandom.com.

${ }^{3}$ Niestety nie każdy film byłem w stanie w ten sposób zidentyfikować. Nie przy wszystkich pozycjach widniały wyżej wymienione dane. Nie ustaliłem kraju pochodzenia piętnastu filmów, natomiast aż przy 165 tytułach nie byłem w stanie jednoznacznie ustalić daty produkcji. Jeżeli w artykule przy jakimś filmie nie widnieje data powstania czy tytuł oryginalny, to znaczy, że nie mogłem ich określić. Z tego względu pojawiające się na wykresach dane nie zawsze są względem siebie w pełni komplementarne. W miarę możliwości zazna- czam przy wykresach zakres wykorzystanych danych.

${ }^{4}$ Zwrócił na to uwagę dziennikarz w rozmowie z zastępcą dyrektora Radiokomitetu, Andrzejem Kurzem: Dla czytelników „Anteny” niezwykle ważna jest wiarygodność tygodniowego programu zamieszczanego w piśmie. Czy możemy mieć pewność, że zmiany dokonywane $w$ ostatniej chwili będa się teraz zdarzać rzadziej? (Dla telewizji - czyli dla widza. Z A. Kurzem rozmawiał J. Peltz, „Antena” 1982, nr 1, s. 3). Również Andrzej Kozieł zwracał uwagę, że jedna trzecia telewidzów dzwoniących do Działu Łączności zgłaszała uwagi do dyscypliny programowej (A. Kozieł, Za chwilę dalszy ciąg programu... Telewizja Polska czterech dekad 1952-1989, Warszawa 2003, s. 202).

${ }^{5}$ J. Kończak, Od Tele-Echa do Polskiego Zoo. Ewolucja programu TVP, Wydawnictwo Akademickie i Profesjonalne, Warszawa 2008, s. 212-213.

${ }^{6}$ Wagę Interwizji dla pozyskiwania treści, w tym filmów, z krajów socjalistycznych potwierdza dokument podsumowujący działalność telewizji w stanie wojennym (Sprawozdanie końcowe zespolu komisarzy wojskowych działajacych $w$ Komitecie do spraw Radia i Telewizji w okresie od 13 grudnia 1981 roku do 25 lipca 1983 roku skierowane do przewodniczacego Komitetu do spraw Radia i Telewizji Mirosła- 
wa Wojciechowskiego). Znajduje się w nim zapis, że w tym czasie telewizja wysłała za granicę 153 filmy i programy (w tym 32 do krajów kapitalistycznych i 26 do krajów rozwijających się), a przyjęła 18 filmów - wszystkie jednak z krajów socjalistycznych, czyli w ramach Interwizji (S. Ligarski, G. Majchrzak, Polskie Radio i Telewizja w stanie wojennym, Instytut Pamięci Narodowej, Warszawa 2011, s. 428).

${ }^{7}$ A. Kozieł, dz. cyt., s. 190.

${ }^{8} \mathrm{~W}$ tym przypadku chodzi o analizę dwóch programów - TP1 i TP2. W stanie wojennym kanał drugi nie zawsze funkcjonował. Zawieszono jego nadawanie 13 grudnia 1981 r. i uruchomiono dopiero w lutym 1982 r. Działał on do końca czerwca 1983 r.. Włączono go ponownie już po zakończeniu stanu wojennego, w październiku $1983 \mathrm{r}$.

${ }^{9}$ Pisząc o krajach socjalistycznych, mam na myśli cały blok wschodni (ZSRR, NRD, Czechosłowacja, Węgry, Rumunia, Jugosławia, Bułgaria), a także takie kraje, jak Chiny, Wietnam czy Kuba. Nie wliczam w ich skład jednak Polski, którą zawsze traktuję osobno.

${ }^{10}$ T. Pikulski, Prywatna historia telewizji publicznej, Muza S.A., Warszawa 2002, s. 221.

${ }^{11}$ Tamże, s. 226-228.

${ }^{12}$ W Decyzji biura politycznego KC PZPR z 13 grudnia 1981 r. można przeczytać, że władza zalecała utrzymanie psychozy stanu wojennego, do czego miała się przyczyniać również telewizja (S. Ligarski, G. Majchrzak, dz. cyt., s. 91). $\mathrm{Z}$ tego powodu w pierwszych dniach stanu wojennego funkcjonował zakaz uruchamiania pozycji relaksowych (tamże, s. 103).

${ }^{13}$ Wyjątkiem jest hiszpański film Josefiny Moliny Obietnica.

${ }^{14}$ Korzystając z ówczesnej nomenklatury, można je nazwać krajami rozwijającymi się.

${ }^{15}$ Trudno ustalić, czy chodzi o film z Nigerii czy Nigru, bowiem w programie opublikowanym w „Antenie” jako kraj produkcji widnieje Nigeria, natomiast na stronie IMDb opisano film jako koprodukcję Nigru z RFN. Podobnie trudno ustalić, kto jest odpowiedzialny za reżyserię. W programie widnieje nazwisko Mustaphy Alassa, natomiast IMDb podaje nazwisko Moustaphy Alassane i Anny Soehring. Problemy z dokładną identyfikacją tego filmu są tylko drobnym odzwierciedleniem kłopotów, jakich nastręcza analiza programów telewizyjnych z okresu PRL.

${ }^{16} \mathrm{~W}$ grudniu wyemitowano, prócz wspomnianych Władców powietrza, Przygód Sindbada i Rebeki, jeszcze amerykański serial Między nami jaskiniowcami (The Flintstones, 1960-1966), austriacko-japońsko-zachodnioniemiecką Pszczółkę Maję (Mitsubachi Māya no Bōken, 1975-1980), amerykańskie Sześć karych koni (The Six Dark Horses, reż. Harry Keller, 1962) i Melodie z tamtych lat (Words and Music, reż. Norman Taurog, 1948), amerykańsko-zachodnioniemieckie Król, dama, walet (King, Queen, Knive, reż. Jerzy Skolimowski, 1972) i szwedzkie Karlsson z dachu (Världens bästa Karlsson, reż. Olle Hellbom, 1974). Natomiast z filmów pochodzących z krajów socjalistycznych pokazano w tym czasie: radzieckie Semurg. Ptak szczęścia (Semurg, reż. Chabibulla Fajzijew, 1972), serial Przygody elektronika (Priklyucheniya elektronika, 1979) i Moskwa nie wierzy tzom (Moskva slezam ne verit, reż. Władimir Mieńszow, 1980), węgierską Maję (rok produkcji i reżyser niezidentyfikowani) oraz odcinek czechosłowackiego serialu $O$ gajowym i jeleniu Wietrzynosku (O hajném Robátkovi a jelenu Vètrnikovi, 1978).

${ }^{17}$ Wyjątkiem jest tu marzec 1982 r., kiedy w ramówce było najwięcej filmów zachodnich, i kwiecień 1982 r., kiedy najwięcej było tytułów polskich. Sytuację tę można tłumaczyć świętami wielkanocnymi. Tradycyjnie w okresie świątecznym w programie pojawiało się znacznie więcej filmów (podobnie jak w wakacje, co dobrze widać na wykresie). Szczególnie chętnie sięgano wtedy właśnie po tytuły polskie oraz zachodnie. W okresie wielkanocnym wyemitowano piętnaście filmów: siedem polskich (m.in. Test pilota Pirxa /1978/ Marka Piestraka, dwuczęściową Panienkę z okienka /1964/ Marii Kaniewskiej i Nie lubię poniedziałku /1971/ Tadeusza Chmielewskiego); trzy amerykańskie (Ludzie z deszczu /The Rain People, reż. Francis Ford Coppola, 1969/, komedie z Haroldem Lloydem oraz horror $\mathrm{Dr}$ Jekyll i Mr Hyde /Dr Jekyll and Mr Hyde, reż. David Winters, 1973/); dwa francuskie (Samotnik /Le sauvage, reż. Jean-Paul Rappeneau, 1975/ i Zwariowany weekend/Le petit baigneur, reż. Robert Dhéry, 1968/ z Louisem de Funèsem w roli głównej); jeden brytyjski (Żółta tódź podwodna /Yellow Submarine, reż. George Dunning, 1968/); jeden, którego kraju produkcji nie udało mi się zidentyfikować (film Maria Callas opisany w programie telewizyjnym jako musical - można jednak domniemywać, że nie była to produkcja socjalistyczna); i zaledwie jeden z bloku wschodniego, z NRD (Nora S. /reż. Georg Schiemann, 1981/). Jak widać na wykresie także rok później, w kwietniu 1983 r., zanotowano dużą liczbę tytułów polskich, niemal równą liczbie filmów z krajów socjalistycznych. 


\section{NIE TYLKO TELERANEK}

18 Zob. E. Fąfrowicz, ...na różowo, „Antena” 1982, nr 1, s. 5; A. Budzyński, $2 x$,Easy Rider”, „Antena” 1982, nr 2, s. 16.

${ }^{19}$ Co ciekawe, bojkot nie dotyczył kinematografii. Jego uczestnicy odmawiali pracy jedynie przy filmach realizowanych w zespołach ,Profil” i „Iluzjon”, kierowanych odpowiednio przez Bohdana Porębę i Czesława Petelskiego (zob. D. Przastek, Środowisko teatru w okresie stanu wojennego, Oficyna Wydawnicza ASPRA-JR, Warszawa 2005, s. 44).

${ }^{20}$ B. Kaźmierczak, Sity na zamiary? „Ekran” 1982, nr 2, s. 18.

${ }^{21}$ M. Rajczuk, Co z filmami w telewizji? ,Ekran” 1983, nr 2, s. 21.

${ }^{22}$ Tamże.

${ }^{23}$ T. Pikulski, dz. cyt., s. 241.

${ }^{24}$ J. Kończak, dz. cyt., s. 195.

${ }^{25}$ E. Zajiček, Poza ekranem: kinematografia polska 1986-2005, Stowarzyszenie Filmowców Polskich, Studio Filmowe Montevideo, Warszawa 2009, s. 282.

${ }^{26}$ W. Loranc, *, „Antena” 1982, nr 1, s. 1.

${ }^{27}$ Dla telewizji - czyli dla widza, dz. cyt., s. 3 .

${ }^{28}$ S. Ligarski, G. Majchrzak, dz. cyt., s. 252.

${ }^{29}$ Podaję za: K. Pokorna-Ignatowicz, Telewizja w systemie politycznym i medialnym PRL. Między polityka a widzem, Wydawnictwo Uniwersytetu Jagiellońskiego, Kraków 2003, s. 198.

30 Tamże, s. 199.

${ }^{31}$ Cyt. za: S. Ligarski, G. Majchrzak, dz. cyt., s. 262.

${ }^{32}$ K. Pokorna-Ignatowicz, dz. cyt., s. 202.

33 J. Bajdor, Gra o wartości, „Antena” 1982, nr 21, s. 2.

${ }^{34}$ Tamże, s. 2-3.

35 T. Pikulski, dz. cyt., s. 243.

36 Tamże, s. 229.

${ }^{37}$ E. Fąfrowicz, dz. cyt., s. 5.

${ }^{38}$ To wyjątkowo chłonna kategoria, do której zaliczają się również komedie obyczajowe czy na przykład filmy historyczne $\mathrm{z}$ rozbudowanym wątkiem obyczajowym. Zestawiam dramat i film obyczajowy razem $z$ tego względu, że w języku angielskim nie funkcjonuje odpowiednik polskiego określenia ,film obyczajowy". Jego odpowiednikiem jest drama, czyli słowo, które znaczeniowo zawiera także istniejące na polskim gruncie określenie „dramat”. Zbierając określenia zarówno z polskiego źródła, jak i z zagranicznego, musiałem połączyć te dwie kategorie.

${ }^{39}$ Komedie amerykańskie to przede wszystkim te z Charliem Chaplinem i Haroldem Lloydem.

${ }^{40} \mathrm{~W}$ zestawieniu podaję tylko dwa kraje, z których pochodziła największa liczba filmów $\mathrm{z}$ danego gatunku.
${ }^{41}$ J. Bajdor, dz. cyt., s. 2.

${ }^{42}$ E. Fąfrowicz, dz. cyt.

${ }^{43}$ Autorka wymieniła jeszcze czechosłowacki serial Szpital na peryferiach (Nemocnice na kraji mesta, 1977-), radziecki trzyczęściowy $D$ 'Artagnan i trzej muszkieterowie (D'Artanyan i tri mushketyora, reż. Georgi Yungvald-Khilkevich, 1979) oraz wielokrotnie powtarzane rodzime Noce $i$ dnie (1975) Jerzego Antczaka, Jezioro osobliwości (1972) Jana Batorego czy Rzeczpospolita babska (1969) Hieronima Przybyła.

${ }^{44}$ E. Fąfrowicz, dz. cyt., s. 5.

${ }^{45}$ Jarzębina czerwona (1969), Kazimierz Wielki (1975), Wraki (1956), Kamienne niebo (1959), Czarne skrzydła (1962), Ogniomistrz Kaleń (1961), Naganiacz (1963), Bilet powrotny (1978).

${ }^{46}$ P. Zwierzchowski, Kino nowej pamięci. Obraz II wojny światowej $w$ kinie polskim lat 60., Wydawnictwo Uniwersytetu Kazimierza Wielkiego, Bydgoszcz 2013.

47 Tamże, s. 63.

${ }^{48}$ Król w Nowym Jorku (A King in New York, 1957), Brzdac (The Kid, 1921), Cyrk (The Circus, 1928), Światła wielkiego miasta (City Lights, 1931), Dzisiejsze czasy (The Modern Times, 1936), Hrabina z Hongkongu (Countess from Hong Kong, 1967).

${ }^{49}$ Wręcz przeciwnie. Wprowadzone w okresie stanu wojennego zmiany legislacyjne poszerzyły kompetencje cenzury, zaostrzając ją (zob. P. Donefner, Na froncie ,walki i porozumienia”. Działalność cenzury w okresie stanu wojennego, w: Cenzura w PRL. Analiza zjawiska, red. Z. Romek, K. Kamińska-Chełminiak, Oficyna Wydawnicza ASPRA-JR, Warszawa 2017).

${ }^{50}$ Notka informacyjna 2/71, AAN, zesp. Główny Urząd Kontroli Prasy, Publikacji i Widowisk, sygn. 3346.

${ }^{51}$ Informacje codzienne o dokonanych ingerencjach, AAN, zesp. Główny Urząd Kontroli Prasy, Publikacji i Widowisk, sygn. 3584.

${ }^{52}$ Przeglad nr 1/71 ważniejszych ingerencji w zakresie publicznej działalności artystycznej za okres od 1 stycznia do 31 marca 1971 r., AAN, zesp. Główny Urząd Kontroli Prasy, Publikacji i Widowisk, sygn. 3294.

${ }^{53}$ K. Klejsa, Filmowe oblicza kontestacji. Kino Stanów Zjednoczonych i Europy Zachodniej wobec kultury protestu przełomu lat sześćdziesiatych i siedemdziesiatych, Wydawnictwo Trio, Warszawa 2008, s. 214-215.

${ }^{54}$ Przegląd $n r 1 / 71$ ważniejszych ingerencji w zakresie publicznej działalności artystycznej za okres od 1 stycznia do 31 marca 1971 r., AAN, 
zesp. Główny Urząd Kontroli Prasy, Publikacji i Widowisk, sygn. 3294.

${ }^{55}$ Notatka, AAN, zesp. Główny Urząd Kontroli Prasy, Publikacji i Widowisk, sygn. 3742.

${ }^{56}$ B. Michalska, Teczka kartonowa z klapkami albo Skurczybyk i inni, „Kwartalnik Filmowy” 2005, nr 49-50, s. 136.

${ }^{57}$ A. Budzyński, dz. cyt., s. 16.

${ }^{58}$ Przegląd nr 1/71 ważniejszych ingerencji w zakresie publicznej działalności artystycznej za okres od 1 stycznia do 31 marca 1971 r., dz. cyt.

59 Zob. S. Grzelewski, Beztroski wędrowiec, „Kino” 1969, nr 46; K. T. Toeplitz, Krytycy o filmach, twórcach, kierunkach 1969, „Kino” 1970, nr 2; L. Armatys, Krytycy o filmach, twórcach, kierunkach 1971, „Kino” 1972, nr 1; A. Kuśniewicz, Krytycy o filmach, twórcach, kierunkach 1971, „Kino” 1972, nr 1; W. Wierzewski, Krytycy o filmach, twórcach, kierunkach 1971, „Kino” 1972, nr 1.

${ }^{60}$ B. Michalska, dz. cyt., s. 136.

${ }^{61}$ Tamże, s. 137.
${ }^{62}$ A polskiej władzy były one nie w smak w sposób szczególny, o czym świadczy zakaz rozpowszechniania Swobodnego jeźdźca, jak również dokumentu Woodstock (reż. Michael Wadleigh, 1970), przedstawiającego słynny festiwal z 1969 r. Jak argumentowano, relacja z tego zgromadzenia, zrealizowana $w$ dodatku $z$ pozycji petnej aprobaty, nie nadaje się do rozpowszechniania $w$ naszych kinach (Przegląd nr 1/71 wazniejszych ingerencji w zakresie publicznej działalności artystycznej za okres od 1 stycznia do 31 marca 1971 r., dz. cyt.). $\mathrm{O}$ bezrefleksyjnym cenzurowaniu treści „hippisowskich” świadczy zarówno blokada niejednoznacznego Swobodnego jeźdźca, jak i nieznajomość kontekstu powstania festiwalu - nazwę miejscowości, w którym się odbywał, podobnie jak tytuł filmu, konsekwentnie pisano z wyjątkowo rzucającym się dziś w oczy błędem, mianowicie Wodstock.

${ }^{63}$ A. Budzyński, dz. cyt., s. 16.

${ }^{64}$ B. Michalska, dz. cyt., s. 136.

${ }^{65}$ A. Budzyński, dz. cyt., s. 16. 